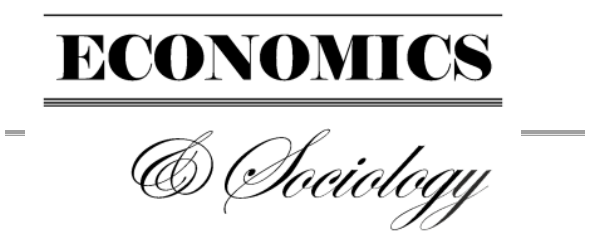

Dana Pal'ová,

Technical University of Košice, Slovakia

E-mail:dana.palova@tuke.sk

ORCID:0000-0002-1515-3507

\author{
Martin Vejačka, \\ Technical University of Košice, \\ Slovakia \\ E-mail:martin.vejacka@tuke.sk \\ ORCID:0000-0002-9761-7597
}

Received: December, 2017

1st Revision: March, 2018

Accepted: July, 2018

DOI: $10.14254 / 2071-$

789X.2018/11-3/6

\section{ANALYSIS OF EMPLOYMENT IN THE EU ACCORDING TO EUROPE 2020 STRATEGY TARGETS}

\begin{abstract}
Unemployment is a long-term problem in many countries worldwide, including European Union. Decreasing unemployment rate has become one of the EU development priorities declared in the Europe 2020 Strategy. Therefore, national policies in this area are coordinated and supported through funding on modernization of education systems, easier access to work, free movement of labor within the EU and support for handicapped people. One of the main objectives of the Europe 2020 Strategy is to achieve a $75 \%$ employment rate for the population aged 24-60. The aim of this contribution is to analyze and evaluate the success in achieving this target by the individual EU Member States. Effects of the selected factors on the employment level are also analyzed. The panel data for the period 2004 to 2016 and all EU countries divided into two clusters has been used. The results show the positive impact of gross domestic product growth and average gross earnings on employment growth. Also, a negative impact of remittances on employment was detected confirming the neoclassical view that received payments are deterring people from the willingness to work.
\end{abstract}

Keywords: employment, Europe 2020 targets, trade openness, remittances, economic growth, foreign direct investment, average gross earnings.
JEL Classification: J21, J24,
C23, F16

\title{
Introduction
}

The European Union consists of 28 economically different countries. National and regional disparities in the EU exist in economic performance between the strong performers at Northern and North-western Europe and the poorer performers in the Southern, Central and Eastern Europe (World Economic Forum, 2014). Therefore, the EU uses the various tools and mechanisms to enable weaker members achieve the stated objectives for the development of the EU as a whole. These objectives are described in Europe 2020, the strategy for European development. The Europe 2020 strategy has highlighted three mutually reinforcing priorities: smart growth, sustainable growth and inclusive growth (European Commission, 2010). The main targets are presented as the desired status of the EU in the year 2020:

- $\quad 75 \%$ of the population aged 20-64 should be employed.

- $3 \%$ of the EU's GDP should be invested in R\&D. 
- $\quad$ The "20/20/20" climate/energy targets should be met (including an increase to $30 \%$ of emissions reduction if the conditions are right).

- The share of early school leavers should be under $10 \%$ and at least $40 \%$ of the younger generation should have a tertiary degree.

- 20 million fewer people should be at risk of poverty (European Commission, 2010).

These objectives are mutually related, for example, higher level of education helps finding work and thus helps increasing employment while reducing poverty. A greater share of research, development and innovation capacity in all the sectors of the economy combined with more efficient use of resources will improve competitiveness and promote jobs' development. Similarly, investing in cleaner, low-carbon technologies might help participate in combating the climate change and creating new opportunities for the employment and entrepreneurship. These objectives require strong political leadership along with an effective mechanism for changing attitudes and the EU procedures so that to achieve the results included in the objectives of the Europe 2020 strategy (European Commission, 2010).

The lifetime of the Europe 2020 strategy is coming to the end and it is important to map the target fulfillment progress in every of the member countries. Monitoring progress and involvement of the EU member states is the key to successful achievement of the strategy targets. For these purposes, there are specific identifiers indicating progress in the implementation process during the strategy lifetime (European Commission, 2013).

Our aim is to focus on the employment objective of the strategy. The main objective of the Europe 2020 strategy in the area of employment is to increase the employment rate of the population aged 20 to 64 from on average $69 \%$ to at least $75 \%$. The employment rate is a measure of the extent to which available labor resources (people available to work) are being used. It is calculated as the ratio of the employed to the working-age population.

The EU's employment target is closely interlinked with the other strategy goals research and development, innovation, education, poverty and social exclusion. Higher levels of education increase employability and higher employment rates can in their turn contribute to economic performance and poverty alleviation, thus addressing the strategy's inclusive growth objective. Moreover, boosting $\mathrm{R} \& \mathrm{D}$ capacity and innovation could improve competitiveness and thus contribute to job creation (European Commission, 2018).

Responsibility for employment and social policy lies primarily on national governments, but the EU funding supports their efforts. To counteract the impact of demographic aging, the EU employment and social policy aim to ease the transition from school to work, allow easier job finding, modernize social security systems, facilitate workers' free movement around the EU, alleviate poverty and protect people with disabilities.

The EU also coordinates and monitors national policies in the area of employment, encouraging member countries to share best practices on social inclusion, poverty, and pensions, supports training, skills development, and entrepreneurship. The European Union also develops laws on workers' rights, discrimination at work and coordination of social security schemes, later monitoring their implementation.

The European Commission encourages EU national governments create more job opportunities and reduce labor market disparities, it also supports economic competitiveness and monitors employment policies in all the EU countries. Furthermore, the EU provides funding programs to support employment (such as the European Social Fund, European Globalization Adjustment Fund, EU Program for Employment \& Social Innovation etc.) (European Commission, 2017).

The EU-28 strives to deliver on the employment targets of the Europe 2020 strategy at the times when the core of the global economic growth moves to Asia and the key trend becomes the emergence of Industry 4.0 associated with higher degrees of automation of many 
work processes. Many concerns arise that automation could lead to further growth of unemployment rates, as many people would be replaced by autonomous machines or programs in multiple job positions. On the other hand, this automation can create many new jobs related to the development and maintenance of these new autonomous working tools. At the same time, it is possible to anticipate transferring of the workforce from automated jobs to other sectors where automation will be less present. Another important aspect might be new innovation paradigms as co-innovation, where new ideas and approaches from various internal and external sources are integrated in a platform to generate values. The coinnovation includes engagement, co-creation, and compelling experience for value creation. Furthermore, these innovation approaches can contribute to social reforms (Lee et al., 2012).

The main aim of this paper is to analyze the successfulness of the EU countries in fulfillment of the main employment objective of the Europe 2020 strategy and to investigate the factors affecting employment and significance of their impact on employment.

\section{Literature review}

The impact of the globalization on employment still plays an important role in current economic policy. Although the globalization is perceived as a threat to workers in developing countries, employment growth in these countries is created by globalization and considered to be a major driver of the poverty reduction. Employment is influenced by the globalization in a variety of ways, through foreign direct investment, growing trade openness and international technology transfer (Jenkins, 2006).

Foreign direct investments (FDI) have an effect on economic growth, wages, technology spillover, foreign trade, employment structure and employment in the host economy (Floyd 2003). Multiple studies (e.g. Braunstein and Epstein (2002), Spiezia (2004), and Vacaflores (2011)) show that the increase in FDI supports the improvements in employment level at the national level. Vacaflores (2011) investigated the effect of the foreign direct investment on employment in Latin American countries with result that FDI has a significant positive effect on the employment generation in the receiving countries.

Lee and Vivarelli (2004) adduced that trade and FDI are expected to positively affect the employment, but generating the employment cannot be automatically expected, while the employment effect might be very heterogeneous in various areas of the world. Spiezia (2004) detected increasing impact of the FDI on the employment with per-capita income with no significant effect in low-income developing countries. Mogab et al. (2013) found a significant effect of the FDI in the countries with less rigid labor markets with the largest additions in the employment.

Also, the results of Liu (2012) suggested, that growth of the FDI in the long period promotes employment, especially in tertiary industry, while in the short term FDI might have a limited or even negative effect on employment. Ernst (2005) also discovered positive impact of the concern FDI on the employment.

Karlsson et al. (2007) detected a relationship between the technology and the employment since better technology improves the competitiveness of the company allowing it to grow even in the term of employee numbers. However, new technology may also decrease demand for low skilled labor by substituting it with fewer high skilled employees.

The findings of Banga (2005) show that the increase of FDI in a sector increases wages rate without an impact on employment in the sector. Also, technological progress was detected as laborsaving.

Brinčíková and Darmo (2014) examined the impact of the FDI inflow on the employment from the macroeconomic perspective in V4 countries without detecting any statistically significant impact of the FDI inflow on the employment. Hence, studies have 
detected often opposite results when investigating the overall impact of the FDI on the employment.

The remittance payments are another aid supporting development as they can increase income in developing countries. Remittances are considered as compensation for emigration, which causes a decrease in the human capital in countries of origin of migrants, but also they can decrease labor supply and increase the income inequality. Blouchoutzi and Nikas (2010) analyzed the effects of remittances in the economies of Albania, Bulgaria, and Romania. The usage of remittances was mainly in the construction, purchase of the capital goods, transport, and financial services.

Gupta et al. (2009) investigated remittance flows to sub-Saharan Africa and detected their direct poverty-mitigating effect and a positive impact on the financial development. Migrant transfers help to ease the immediate budget constraints of the recipient households and provide an opportunity for small savers to gain a foothold in the formal financial sector. León-Ledesma and Piracha (2004) analyzed the impact of the payments received on the employment of Central and Eastern European countries, demonstrating that received payments have a positive effect on the productivity and the employment.

Eichhorst et al. (2010) imply that countries that have a strong internal flexibility can better control the rising unemployment. The European Commission (2010b) states that trade openness also contributes to achieving the objectives of the Europe 2020 strategy in terms of boosting economic growth, creating more jobs, increasing income, and increasing employment. The effects of trade on the employment after longer periods should be positive, although in shorter periods it may cause adverse effects, while it may cause reallocation of workers across sectors.

Jayanthakumaran (2006) investigated the effects of trade on employment in Australia and detected the significant positive impact of the earnings in the manufacturing industry and the negative correlation of the trade openness with employment. Jenkins and Sen (2006) detected that trade led to a significant increase in technological progress and consequently, a fall in employment for a given level of output. Sen (2008) analyzed the impacts of trade on the employment in India during a long period ( 25 years) with finding its minimal impact in the manufacturing sector.

In general, multiple studies (e.g. Döpke, 2001, Kapsos, 2005 etc.) adduce a positive and strong relationship between economic growth and employment. However, economic growth generates new jobs with different intensity in various countries and periods, what reflects the different response of the labor market to the economic growth process. Herman (2011) detected the existence of a low employment elasticity of economic growth in EU with significant differences from one country to another suggesting that European countries have a small capacity to generate employment under the conditions of the existence of an economic growth process. Therefore, it is highly important to increase the employment intensity of economic growth to assure the conditions for economic and human development.

Neoclassical and Keynesian theories contain opposing predictions of the real wage changes causing variations in the levels of employment. Neoclassical economy assumes perfect labor market, where institutional interventions only distort its efficiency. The neoclassical model claims that decreasing wages will increase employment. In contrast, Keynesian models declare that changes in real wages will create changes in the level of employment, therefore, when workers perceive their wages to be too low, they prefer to idle. The results of Suedekum and Blien (2004) spoke in favor of the neoclassical theory, indicating a negative relationship between wages and employment for former West Germany. Apergis and Theodosiou (2008) indicated a long-term relationship between the real wages and employment, suggesting that the reduction in real wages is not large enough to induce an increase in production and employment. Stanila et al. (2014) investigated the evolution of the 
main relevant macroeconomic indicators for the European Union upon employment rate using hierarchical cluster analysis. Their results indicate a positive influence of earnings and gross domestic product growth on employment rate in all EU member states during the period of $2000-2011$.

Though, the most of studies lack a comprehensive analysis of the factors affecting employment in EU28 countries in the context of achieving the Europe 2020 employment objective. Several studies investigate some of the factors influencing employment (or unemployment) individually. Palan and Schmiedeberg (2010) tested the structural convergence for Western European countries using employment data. The divergence was obvious in technology-intensive manufacturing industries. Zaharia and Balacescu (2013) examined convergence of the EU28 member states in employment in period of 2000-2012 detecting the divergence process. Group of developed countries converge to the values of the employment rate well above the European average, while the majority of the former communist EU28 member countries, converge to the values of the employment rate below the European average. SSerb et al. (2016) detected that population growth automatically generates an increase in employment levels, which is also influenced by migration of mainly young graduates migrating to other countries where labor is better paid. Simionescu et al. (2016) observed the annual average of employment as the main factor of the GDP growth. Hančlová et al. (2012) examined the factors influencing the long-term unemployment rate in the European Union countries in the period of 2001-2010. Their results showed that GDP growth stimulated decrease of unemployment. Also, tax burden on labour and flexibility of the labour affected the long-term unemployment in both original and new member states of EU.

\section{Methodological approach}

The aim of the article is to assess the results of EU countries in terms of integrating Europe 2020 program's employment objective and to identify and analyze the impact of the various factors affecting the employment rate in EU countries. As input data, the data of the EU28 Member States are available for the analysis in the timeframe from 2004 to 2016. This data was obtained from the database of Eurostat. Headline employment target of Europe 2020 strategy was fulfilled in seven countries of EU (Czech Republic, Germany, Estonia, Ireland, Latvia, Lithuania, and Sweden) in 2016 already. The most distant from employment target fulfillment are countries with post-crisis economic and unemployment problems (Greece, Spain, Bulgaria or Italy). The United Kingdom lacks the data on target employment rate and its fulfillment as it is in the process of leaving the European Union. Any economic recession before the year 2020 may further change the levels of fulfillment of the objective in a negative way. Employment data were used in the further investigation of the factors influencing employment in EU 28 countries.

Based on the literature review, the most important parameters influencing employment (EMP) were defined as foreign direct investment (FDI), remittances payments (REM), trade openness (TRA), gross domestic product growth (GDP) and average gross earnings (EAR). These parameters are similar to the model used in the study of Stanila et al. (2014).

The employment rate indicator (EMP) in our analysis is expressed in percentages as the share of working people in $20-64$ age group on the total population of the same age group. The indicator is based on the EU labor force survey. The survey covers the entire population living in households excluding collective housing facilities (such as dormitories, hospitals etc.). The employed population consists of persons who, during the reference period, did some work for wages or profit for at least an hour or did not work, but had a job, in which they were temporarily absent. The annual average gross earnings (EAR) is expressed in euro 
for a single childless person. These two indicators were obtained from the Eurostat database (Eurostat, 2017).

Following Table 1 contains rates of the employment in the year 2010 in comparison with the employment rate in the year 2016, followed by the country's objective employment rate desired in the year 2020. The last column contains fulfillment of the employment target in 2016. The year of 2010 was considered due to the fact that it was the year of introduction of the Europe 2020 strategy and the starting point in an effort to fulfill it. The year of 2016 is the most recent year with data available at the time of data collection.

Table 1. Europe 2020 employment target fulfillment of EU countries

\begin{tabular}{lcccc}
\hline Country & 2010 & 2016 & Target $(2020)$ & Target fulfillment (\%) \\
\hline EU(28) & 68.6 & 71.1 & 75 & 94.8 \\
\hline Belgium & 67.6 & 67.7 & 73.2 & 92.5 \\
\hline Bulgaria & 64.7 & 67.7 & 76 & 89.1 \\
\hline Czech Republic & 70.4 & 76.7 & 75 & 102.3 \\
\hline Denmark & 75.8 & 77.4 & 80 & 96.8 \\
\hline Germany & 75 & 78.6 & 77 & 102.1 \\
\hline Estonia & 66.8 & 76.6 & 76 & 100.8 \\
\hline Ireland & 64.7 & 70.3 & 69 & 101.9 \\
\hline Greece & 63.8 & 56.2 & 70 & 80.3 \\
\hline Spain & 62.9 & 63.9 & 74 & 86.4 \\
\hline France & 69.4 & 70.0 & 75 & 93.3 \\
\hline Croatia & 62.1 & 61.4 & 62.9 & 97.6 \\
\hline Italy & 61 & 61.6 & 67 & 91.9 \\
\hline Cyprus & 75 & 68.7 & 75 & 91.6 \\
\hline Latvia & 64.3 & 73.2 & 73 & 100.3 \\
\hline Lithuania & 64.3 & 75.2 & 72.8 & 103.3 \\
\hline Luxembourg & 70.7 & 70.7 & 73 & 96.8 \\
\hline Hungary & 59.9 & 71.5 & 75 & 95.3 \\
\hline Malta & 60.1 & 69.6 & 70 & 99.4 \\
\hline Netherlands & 76.8 & 77.1 & 80 & 96.4 \\
\hline Austria & 73.9 & 74.8 & 77 & 97.1 \\
\hline Poland & 64.3 & 69.3 & 71 & 97.6 \\
\hline Portugal & 70.3 & 70.6 & 75 & 94.1 \\
\hline Romania & 64.8 & 66.3 & 70 & 94.7 \\
\hline Slovenia & 70.3 & 70.1 & 75 & 93.5 \\
\hline Slovakia & 64.7 & 69.8 & 72 & 96.9 \\
\hline Finland & 73 & 73.4 & 78 & 101.5 \\
\hline Sweden & 78.1 & 81.2 & 80 & - \\
\hline United Kingdom & 73.5 & 77.5 & - & \\
\hline & & & & \\
\hline
\end{tabular}

Source: own compilation from Eurostat (2017)

Trade openness (TRA) is the sum of the export and import of goods and services, expressed as a percentage of GDP, and the payments received are considered to be the amounts collected from each country as a percentage of GDP. Foreign direct investment (FDI) represents a foreign direct investment inflow, this indicator is also expressed as a percentage of GDP. The last indicator gross domestic product (GDP) growth is the annual growth rate of GDP, expressed as a percentage. The source for these indicators are the databases of World Bank (World Bank, 2017). 
Greene (2002) considers as a basic regression model of the panel data model in the following form:

$$
y_{i t}=\beta_{1} x_{i t 1}+\beta_{2} x_{i t 2}+\ldots+\beta_{k} x_{i t k}+\alpha_{1} z_{i 1}+\alpha_{2} z_{i 2}+\ldots+\alpha_{q} z_{i q}+\varepsilon_{i t}
$$

In this model $x_{1}$ to $x_{k}$ are explanatory variables not including the constants, $y$ is the variable to be explained, and the variables $z_{1}$ to $z_{q}$ represent the individual effects, i.e. the diversity that the individual or group may differ from other entities.

Individual effects may already contain constants and sets of individual or groups of the specific variables that can be observed (such as race, gender, location and alike) and their effects will not change over time. Based on this framework, three cases can be distinguished: a joined regression model, a fixed-effect model, and a random-effects model (Greene, 2002). Further mentioned tests were used to identify the type of model.

Based on the model defined by equation (1), testing was performed in programming language R. Firstly, a model was based on all observations, but since EU28 countries have significant differences among them, the division using cluster analysis into clusters consisting of the similar countries in terms of employment rates was employed. Two clusters were created similarly to the method of Stanila et al. (2014). Consequently, the estimation of the regression models of panel data was conducted for each cluster of the countries and particular countries, and the indicators that affect the employment rate of each cluster were highlighted.

In the estimation of the regression models for panel data, for all the observations together and for each cluster separately, the estimated model was tested. The compliance with the statistical assumptions given for the particular type of models was investigated. First, in each model, Chow's test for poolability was performed to test the panel data structure presence. Then the significance of time and individual effects in the model was tested using the F-test and Lagrange Multiplier test. Further, the sequence dependence (using Wooldridge test, Breusch-Godfrey test, and Wooldridge's short-range test), cross-sectional dependence (Pesaran CD test), stationary (Maddala-Wu unit root test for panel data), and heteroscedasticity (Breusch-Pagan test) were tested. Hausman's test was also used to determine whether a random or fixed effect test is appropriate, but if spatial or sequence dependence exists in the model, the random effect estimator is not effective and the Hausman test can be distorted (Greene, 2017).

\section{Conducting research and results}

At first, a panel data analysis for all observations was performed. Overall observation consists of data for EU 28 countries during 13 years and 364 observations. Multiple individual effects not changing over time were present and also cross-sectional dependence and heteroscedasticity were detected. There was also stationarity that is desirable (the time series $S_{t}$ is called stationary when its mean and variance are constant over time and its covariance is between $S_{t}$ and $S_{t+}$ depends only on $k$ and not on $t$ ).

In order to verify the suitability of the model, the Hausman test was used with result that the model with both fixed and random effects cannot be used. Furthermore, in our model, a sequence and cross-sectional correlation were also present, so the random effect estimator is not effective and the Hausman test can be distorted (Želinský, 2013; Greene, 2017). Therefore, the use of the model with fixed effects is sounder.

The fixed effects model has individual effects $z_{1}$ to $z_{q}$ not observable but correlated with explanatory variables, so the solution is to include all effects into the estimated 
constrained mean by relation (2), and the model with fixed effects has the shape (3). Fixed effect $a_{i}$ means a specific constant for each cross-section entity (Lukáčik et al., 2011).

$$
\begin{gathered}
\alpha_{i}=\alpha_{1} z_{i 1}+\alpha_{2} z_{i 2}+\ldots+\alpha_{q} z_{i q} \\
y_{i t}=\alpha_{1}+\beta_{1} x_{i t 1}+\beta_{2} x_{i t 2}+\ldots+\beta_{k} x_{i t k}+\varepsilon_{t}
\end{gathered}
$$

So the employment formula (4), based on the above-explained dependencies of the individual explanatory variables on the explicated employment rate, corresponds with Stanila et al. (2014) and has following general shape:

$$
E M P_{i t}=\alpha_{i}+\beta_{1} F D I_{i t}+\beta_{2} R E M_{i t}+\beta_{3} T R A_{i t}+\beta_{4} G D P_{i t}+\beta_{5} E A R_{i t}+\varepsilon_{i t}
$$

The formula (4) represents the fixed-effects model where:

$E M P_{i t}-$ is employment, which is an explained variable;

$\alpha_{i}-$ is a fixed effect;

$G D P_{i t}$ - gross domestic product growth - explanatory variable;

$R E M_{i t}$ - remittances - received payments - explanatory variable;

$E A R_{i t}$ - average gross earnings - explanatory variable

$F D I_{i t}$ - foreign direct investment - explanatory variable;

$T R A_{i t}$ - trade openness - explanatory variable;

$\varepsilon_{i t}$ - random model error;

$i$ - cross-sectional dimension - individual countries;

$t$ - time dimension.

Statistically insignificant variables were removed from the model and found that employment in all the countries is dependent on received payments, annual growth rates of Gross Domestic Product, and Average gross earnings. The adjusted coefficient of determination (R squared) in Table 2 shows that approximately $3.9 \%$ of the total variability of the dependent variable is explained by the specified model, the remaining variability is caused by the other factors and the element of chance.

Table 2. Tests results summarization

\begin{tabular}{llll}
\hline Variables & REM, GDP, EAR & & \\
\hline Sample size & $\mathrm{n}=28, \mathrm{~T}=13, \mathrm{~N}=364$ & Diagnostic test & \\
\hline$\beta 1(\mathrm{FDI})$ & $-3.92 \mathrm{e}-03$ & Chow test of poolability & $2.2 \mathrm{e}-16$ \\
& $(0.324533)$ & & $2.2 \mathrm{e}-16(0.07186)$ \\
\hline$\beta 2(\mathrm{REM})$ & $-0.58223402^{*}(0.005226)$ & $\mathrm{F}$ test & $2.2 \mathrm{e}-16$ \\
\hline$\beta 3(\mathrm{TRA})$ & $-1.34 \mathrm{e}-02$ & LM test & \\
& $(0.197220)$ & & $0.0001449^{*}$ \\
\hline$\beta 4(\mathrm{GDP})$ & $0.15103676^{*}$ & Sequential correlation & \\
& $(2.631 \mathrm{e}-05)$ & & $2.2 \mathrm{e}-16^{*}$ \\
\hline$\beta 5(\mathrm{EAR})$ & $0.00029041^{*}$ & Cross-sectional dependence & \\
& $(6.063 \mathrm{e}-07)$ & Stationarity & $2.2 \mathrm{e}-16^{*}$ \\
\hline R squared & 0.11817 & Heteroscedasticity & $0.02027^{*}$ \\
\hline adjusted R squared & 0.03873 & & \\
\hline
\end{tabular}

Source: own compilation based on Eurostat database (2017), *-significant at 0.05 level, $n-$ the number of cross-sectional units, $T$ - the length of the time series, $N$-total number of observations, brackets contain estimates of standard errors 
However, since it is a panel data model, the overall coefficient of determination is inaccurate, the larger the cross-sectional dimension of the model $(\mathrm{N})$ and the smaller time dimension of the model $(\mathrm{T})$ is, the coefficient of determination has a higher resolution ability and better approximates the coefficient of determination from the linear regression. Since heteroscedasticity, sequence and cross-sectional dependence are present in our model, to avoid misconceptions and wrong conclusions about the significance of the regression coefficients, the robust variance-covariance matrix must be estimated (Želinský, 2013). The model will be interpreted with the use of the variance-covariance matrix and results can be seen in equation (5), all variables being statistically significant.

$$
E M P_{i t}=\alpha_{i}-0.582 R E M_{i t}+0.151 G D P_{i t}+0.0003 E A R_{i t}
$$

The equation (5) shows that if the size of the received payments increases by $1 \%$, the employment rate will be reduced by only $0.58 \%$. The rise in GDP growth rate by a $1 \%$ will trigger a $0.15 \%$ increase in the rate of employment. Average gross earnings have a negligible impact on employment in these countries.

Table 3. Granger causality test

\begin{tabular}{llllll}
\hline $\begin{array}{l}\text { Variables Granger-causing } \\
\text { Employment }\end{array}$ & $\mathrm{F}$ & $\mathrm{p}$ & $\begin{array}{l}\text { Employment Granger- } \\
\text { causing Variable }\end{array}$ & $\mathrm{F}$ & $\mathrm{p}$ \\
\hline FDI & 3.0175 & 0.08322 & FDI & 0.2178 & 0.6410 \\
\hline REM & 2.7297 & 0.09937 & REM & 0.2703 & 0.6034 \\
\hline TRA & 2.6004 & 0.10770 & TRA & 0.0055 & 0.9411 \\
\hline GDP & 4.2138 & $0.04082^{*}$ & GDP & 22.780 & $2.65 \mathrm{e}-$ \\
& & & & & $6^{* *}$ \\
\hline EAR & 3.3383 & 0.06851 & EAR & 0.6274 & 0.4288 \\
\hline
\end{tabular}

Source: own computation based on gathered data, * significant at 0.05 level, ** significant at 0.01 level (361 data points, lag value $=1$ )

Furthermore, Granger causality test was performed to confirm the results. Its results are presented in Table 3. The influence of GDP growth on employment was confirmed at significance level of 0.05 . Also, the other side of dependences was tested by Granger causality test detecting significant influence of employment on GDP growth (at significance level of 0.01). This result is in accord with the results of Simionescu et al. (2016) and Radulescu et al. (2018). Causality testing showed two-way dependence of GDP growth and employment which are strongly interconnected.

Considering the fact that each of the 28 member states has different characteristics, the hierarchical cluster analysis was employed. The hierarchical cluster analysis using a unsupervised learning allows assigning a set of observations into subsets (clusters) with similar characteristics. The cluster technique was based on the Ward's minimum variance method and the intervals were calculated using the squared Euclidean distance. Based on the size of the employment rate indicator throughout the whole surveyed period, two clusters of countries were created. Each country forms a separate cluster at the lowest level of cluster analysis, with these countries gradually clustering to larger clusters, according to similarity in employment rate. Based on the dendrogram (Figure 1), all countries were divided into two clusters similarly as in Stanila et al. (2014). 


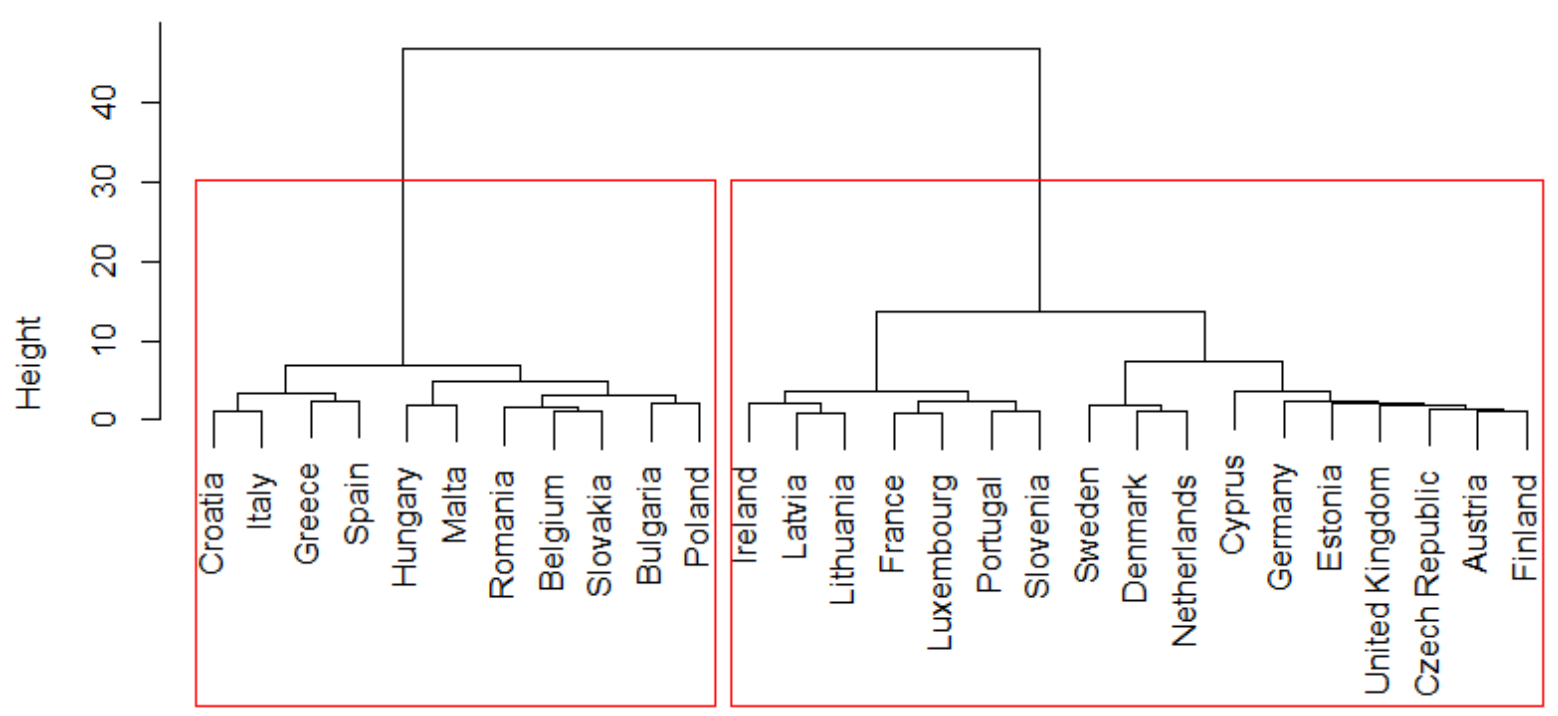

Figure 1. The similarity of Countries - Dendrogram Source: own compilation

The following two clusters of considered countries were results of Ward's cluster analysis conducted on our data:

- Cluster 1: Croatia, Italy, Greece, Spain, Hungary, Malta, Romania, Belgium, Slovakia, Bulgaria, Poland.

- Cluster 2: Denmark, Sweden, Netherlands, Cyprus, United Kingdom, France, Luxembourg, Czech Republic, Austria, Germany, Lithuania, Slovenia, Finland, Ireland, Portugal, Estonia, Latvia.

Following Figure 2 shows the two clusters. The distribution of clusters suggests that the first cluster (represented in red) is composed of economies with lower employment and the second one (represented in blue) contains better-performing countries.

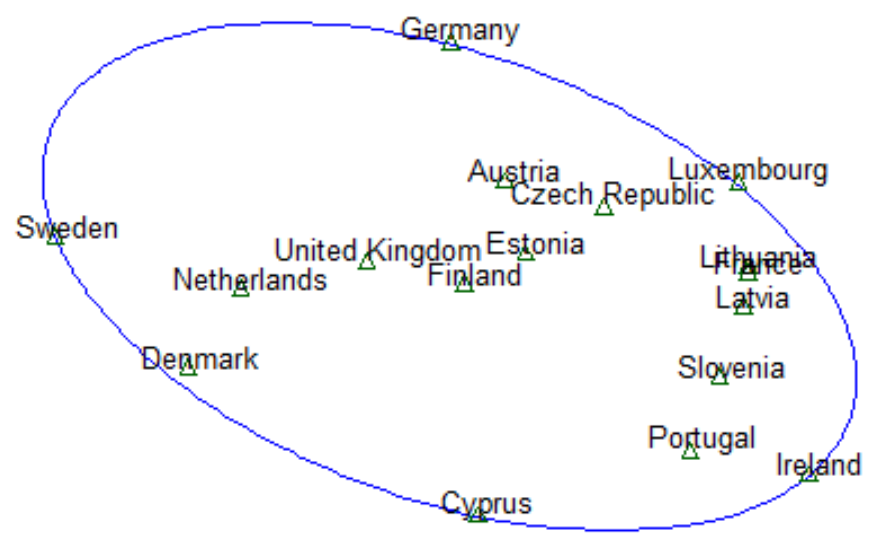

Figure 2. Distribution of EU member states into clusters Source: own compilation

In comparison with Stanila et al. (2014), our first cluster includes Lithuania, Latvia, and Ireland among the developed countries. Our model also includes Croatia as a new member country of the EU. A smaller variance in cluster content was due to the fact that we 
considered other periods and more recent data. Subsequently, the panel data for both clusters were analyzed, the results of which are shown in Table 4.

Table 4. Tests results summarization for both clusters

\begin{tabular}{lll}
\hline & \multicolumn{1}{c}{ Cluster 1 } & \multicolumn{1}{c}{ Cluster 2 } \\
\hline Variables in model & REM, GDP, EAR & TRA, GDP, EAR \\
\hline Sample size & $\mathrm{n}=11, \mathrm{~T}=13, \mathrm{~N}=143$ & $\mathrm{n}=17, \mathrm{~T}=13, \mathrm{~N}=221$ \\
\hline$\beta 1(\mathrm{FDI})$ & 0.00517284 & -0.00111652 \\
& $(0.4001766)$ & $(0.867630)$ \\
\hline$\beta 2(\mathrm{REM})$ & $-0.63370250 *$ & -0.43072082 \\
& $(0.0439526)$ & $(0.137033)$ \\
\hline$\beta 3(\mathrm{TRA})$ & -0.02589536 & $-2.2769 \mathrm{e}-02 *$ \\
& $(0.2215697)$ & $(0.0563127)$ \\
\hline$\beta 4(\mathrm{GDP})$ & $0.26243637^{*}$ & $0.14417 *$ \\
& $(0.0004579)$ & $0.0003678)$ \\
\hline$\beta 5($ EAR $)$ & $0.00055604 *$ & $2.3319 \mathrm{e}-04 *$ \\
& $(2.513 \mathrm{e}-06)$ & $0.0019450)$ \\
\hline R squared & 0.21616 & 0.081205 \\
\hline adjusted R squared & 0.13716 & 0.005646 \\
\hline Chow test of poolability & $4.967 \mathrm{e}-14$ & $2.2 \mathrm{e}-16$ \\
\hline F test & $2.13 \mathrm{e}-11(0.000998)$ & $2.2 \mathrm{e}-16(0.01899)$ \\
\hline LM test & $2.98 \mathrm{e}-13$ & $2.2 \mathrm{e}-16$ \\
\hline Sequential correlation & $0.01793^{*}$ & $0.02084 *$ \\
\hline Cross-sectional dependence & $5.161 \mathrm{e}-05 *$ & $2.2 \mathrm{e}-16 *$ \\
\hline Stationarity & $2.2 \mathrm{e}-16 *$ & $2.2 \mathrm{e}-16 *$ \\
\hline Heteroscedasticity & $0.08833^{* *}$ & $0.828 * *$ \\
\hline
\end{tabular}

Source: own compilation, * - significant at 0.05 level, ** - heteroscedasticity not present- the number of cross-sectional units, $T$ - the length of the time series, $N$-total number of observations, brackets contain estimates of standard errors

The panel data model can be considered fixed effects model, if the individual effects are correlated with explanatory variables. Alternatively, the individual effects are incorporated into the error term and assumed uncorrelated with the explanatory variables and then the panel data model is considered random effects model (Baum, 2001). The most used estimator for the fixed effects models is the within estimator. The consistent estimation is possible even with endogenous regressors. For the estimation of a random effects models the general least square method is used. An advantage of the random effects model is that it allows using explanatory variables that are constant over time. The model is estimated assuming that the default standard errors are independent, identically distributed and homoscedastic (Cameron and Trivedi, 2010). When heteroskedasticity is present it is necessary to compute robust standard errors.

The Hausman test showed the probability less than $5 \%$ for both cases indicating the fixed-effects model. The models for the two clusters using the within estimator was estimated. Wald test for heteroskedasticity and the serial correlation test showed the errors being autocorrelated and heteroskedastic. Therefore, a robust fixed-effects regression with Driscoll and Kraay standard errors was estimated.

The first cluster consists of 11 countries, data for 13 years and 143 observations. As for a given cluster, as with a previous analysis made up of all the countries, there is also a crosssectional and sequential correlation, so we use a variance-covariance matrix for interpretation. 
Hausman's test results may be distorted and therefore a more cautious model of the fixed effects will be used.

Statistically insignificant variables were removed from the model, leaving only REM, GDP, and EAR. In this model, individual effects change over time. The second cluster consists of 17 countries, data for 13 years and 221 observations. Even in this cluster, there is a cross-sectional and sequential correlation, so the results of the Hausman test are not taken into account as they may be distorted. For this reason, the fixed effects model will be used as in previous cases. After removing the statistically insignificant explanatory variables from the general model, trade openness, GDP growth and average gross earnings remained in the model.

The model in the first cluster will be interpreted using a robust variance-covariance matrix. The matrix results can be seen in equation (6), using this matrix, the significance of received payments is lost, all the other variables are statistically significant.

$$
E M P_{i t}=\alpha_{i}+0.262 G D P_{i t}+0.0006 E A R_{i t}
$$

Equation (6) shows that a $1 \%$ increase in GDP growth rate results in a $0.26 \%$ increase in employment rates. Average gross earnings have a negligible impact on employment in these countries. If the model would not be interpreted using a variance-covariance matrix, then the most intense relationship would be between direct payments and employment at the rate of $0.6 \%$.

Table 5. Fixed effects in the first cluster

\begin{tabular}{ll}
\hline Country & Fixed effect (\%) \\
\hline Bulgaria & 64.73 \\
\hline Slovakia & 62.13 \\
\hline Romania & 62.11 \\
\hline Hungary & 60.35 \\
\hline Poland & 59.42 \\
\hline Croatia & 58.15 \\
\hline Malta & 55.25 \\
\hline Belgium & 54.5 \\
\hline Spain & 53.6 \\
\hline Greece & 52.34 \\
\hline Italy & 50.81 \\
\hline
\end{tabular}

Source: own compilation

In Table 5, the fixed effects of the individual countries belonging to the first cluster are shown. It represents the value of the employment rate in that country if none of the statistically significant explanatory variables (GDP, EAR) changes. Bulgaria would have the highest employment and the lowest employment in this cluster would be in Italy.

The model of the second cluster by means of the variance-covariance matrix will be interpreted. The results of the matrix are shown in the equation (7), using this matrix the significance of the trade openness is lost, but other variables are statistically significant.

$$
E M P_{i t}=\alpha_{i}+0.144 G D P_{i t}+0.0002 E A R_{i t}
$$


Equation (7) shows that a $1 \%$ increase in GDP growth rate results in a $0.14 \%$ increase in employment rates. In this case, the average gross earnings also have a negligible impact on the employment rate in these countries. If the model would not be interpreted using a variance-covariance matrix, then there would be a significant relationship between trade openness and employment at the rate of $0.02 \%$.

Table 6 shows the fixed effects of the individual countries belonging to the second cluster, i.e. the value of the employment in the given country unless one of the explanatory variables, that have a statistically significant relation to employment, is not changed.

Table 6. Fixed effects in the second cluster

\begin{tabular}{lc}
\hline Country & Fixed effect (\%) \\
\hline Sweden & 74.13 \\
\hline Estonia & 73.84 \\
\hline Czech Republic & 72.50 \\
\hline Netherlands & 72.47 \\
\hline Denmark & 72.42 \\
\hline Lithuania & 71.13 \\
\hline Cyprus & 70.53 \\
\hline Latvia & 70.41 \\
\hline Slovenia & 70.26 \\
\hline Germany & 69.66 \\
\hline Austria & 69.19 \\
\hline Portugal & 69.12 \\
\hline Finland & 69.02 \\
\hline Luxemburg & 68.87 \\
\hline United Kingdom & 68.42 \\
\hline Ireland & 66.09 \\
\hline France & 65.14 \\
\hline
\end{tabular}

Source: own compilation

Table 6 shows the value of employment rate in that country unless one of the explanatory variables in our model that have a statistically significant relationship with employment (GDP, EAR) is changed.

\section{Conclusion}

Our first model, including all countries, shows a statistically significant relationship between employment rates and gross domestic product, direct payments, and average gross earnings. Only payments received have had an inverse relationship with employment. Foreign direct investments and trade openness have been statistically insignificant in this case. In the first clustered model with less developed countries, a statistically significant relationship was between the employment rates and the economic growth and the average gross earnings, leaving remittances excluded from the model as they lost significance by the use of the variance-covariance matrix. Stanila et al. (2014) detected (apart from these two variables) also remittances as statistically significant in less advanced countries.

When considering the effects of the gross domestic product, a $1 \%$ increase in gross domestic product growth will cause relatively low $(0.26 \%)$ increase in employment rates in less developed countries. This indicates that if the GDP growth rate will increase by more than $3.85 \%$, it will increase the employment rate by more than $1 \%$. One possible explanation 
for this situation may be the fact that GDP growth may be based on technological progress, which results in capital substitution, and thus a drop in employment rates. Even if these countries would not be directly involved in technological progress, they would be foreign direct investment beneficiaries resulting in significant technological benefits. Also, revenue generated by GDP is not sufficient to support sustainable development in services, with the view to achieving significant increase in employment rates (due to the fact that, due to low labor productivity, services absorb more labor than other sectors in the national economy). The level of correlation supports the hypothesis that labor force growth is more likely to be supported by structural changes than changes in the gross domestic product (Stanila et al., 2014).

The relationship between the employment rates and the real wages is very weak in this case and contrary to the neoclassical assumption of a negative correlation between them. The reason may be that the average annual gross income indicator for a single childless person may not represent the real wage.

For the second cluster containing advanced countries, the obtained model expresses a statistically significant relationship between the employment rate and the gross domestic product and the average gross earnings. The trade openness from the model had to be excluded because of losing its significance while using the variance-covariance matrix. Only trade openness had an inverse relationship with employment. In the article, besides the average gross earnings, positive dependence was also shared with trade openness and remittances. In this case, a $1 \%$ increase in GDP growth will trigger a $0.14 \%$ increase in employment, i.e. to raise the employment rate by at least $1 \%$, the growth rate of GDP must increase by $7.14 \%$.

All three models indicate a positive relationship between employment and GDP, but also between employment and average gross earnings, although very weak. The model with all the countries detected the inverse relationship between employment and remittances, which was present also in the model for the cluster of less developed countries, but it was not considered due to correlation. Remittances had a negative impact on the employment, which confirms the view of the neoclassical theorists that the received payments are deterring people from the willingness to work. Only in advanced countries, a statistically significant negative relationship between employment and trade openness was detected, but it was not considered due to correlation.

Thus, EU28 countries should support the GDP growth, in order to increase employment rates in their economy. The growth of GDP can be supported (alongside with employment growth) by increasing research, development and innovation capacity in all sectors of the economy. The investments into the infrastructure and physical to improve productivity and also increase economic output. EU supports these investments, for example, through the European Structural and Investment Funds. The more efficient use of resources may promote new job development and improve competitiveness of the economies and also support climate and energy objectives of the strategy. The investments into human capital through higher educational levels of potential employees will increase their employability. The raising of higher participation rate (the number of persons in the labor force as a percentage of the working age population) can also reduce the risk of poverty, while addressing the strategy's inclusive growth objective. The higher employment rates initialized by economic growth supports, and at the same time, is supported by other objectives of Europe 2020 strategy, indicating that this strategy has a chance to become successful. Important issue is to carefully to monitor, evaluate and support performance of countries in the context of the Europe 2020 strategy. 


\section{References}

Apergis N., \& Theodosiou I. (2008). The Employment - Wage Relationship: Was Keynes right after all?. American Review of Political Economy, 6(1), 40-50.

Banga, R. (2005). Liberalisation and Wage Inequality in India. [Working Paper Series] New Delhi: Indian Council for Research on International Economic Relations (ICRIER). 30 p. ICRIER WP No. 156.

Baum, C. F. (2001). Residual diagnostics for cross-section time series regression models. The Stata Journal, 1(1), 101-104.

Blouchoutzi, A., \& Nikas, C. (2010). The macroeconomic implications of emigrants' remittances in Romania, Bulgaria, and Albania. Post-Communist Economies, 22, 547558. doi: 10.1080/14631377.2010.518479.

Braunstein, E., Epstein, G. (2002).Bargaining Power and Foreign Direct Investment in China: Can 1.3 Billion Consumers Tame the Multinationals? [Working Paper Series] Massachusetts: Political Economy Research Institute. 41 p. WP No. 45.

Brinčíková, Z., Darmo, L. (2014).The Impact of FDI Inflow on Employment in V4 Countries. European Scientific Journal, special edition 1, 506-510.

Cameron, A. C., Trivedi, P. K. (2010). Microeconometrics Using Stata. Stata Press.

Döpke, J. (2001).The Employment Intensity of Growth in Europe [Working Paper] Kiel: Kiel Institute of World Economies. 49p. WP No. 1021.

Eichhorst W., Escudero V., Marx P., Tobin S. (2010). The impact of the crisis on employment and the role of labor market institutions. [Discussion Papers.] Bonn: The Institute for the Study of Labor (IZA). 34 p. IZA DP No. 5320.

Ernst, Ch. (2005). The FDI - employment link in a globalizing world: The case of Argentina, Brazil and Mexico. [Employment strategy papers] Geneva: International Labour Office (ILO). 52p. ILO ESP No. 2005/17.

European Commission (2010a). EUROPE 2020 - A strategy for smart, sustainable and inclusive growth. <http://eur-lex.europa.eu/LexUriServ/LexUriServ.do?uri= COM:2010:2020:FIN:EN:PDF>.

European Commission (2010b). Trade as a driver of prosperity. Retrieved May 5, 2018, from <http://trade.ec.europa.eu/doclib/docs/2010/november/tradoc_146940.pdf>.

European Commission (2017). Employment and social affairs. Retrieved May 4, 2018, from <https://europa.eu/european-union/topics/employment-social-affairs_sk>.

European Commission (2018). Smarter, greener, more inclusive? - Indicators to support the Europe 2020 strategy - 2018 edition. Retrieved August 4, 2018, from < http://ec.europa.eu/eurostat/en/web/products-statistical-books/-/KS-02-18-728 >.

European Social Fund (2015). Other EU funds that support employment.Retrieved April 28, 2018, from <http://ec.europa.eu/esf/main.jsp?catId=34\&langId=sk>.

Eurostat (2017).Employment rate by sex, age group 20-64.Retrieved April 25, 2018, from $<$ http://ec.europa.eu/eurostat/tgm/table.do?tab=table \&init $=1 \&$ language $=$ en $\&$ pcode $=\mathrm{t} 20$ 20_10\&plugin $=1>$.

Floyd, D. (2003). FDI Through Cross-Border Acquisitions and Greenfield Investment in Poland. Journal of East-West Business, 9(3/4), 53-72.

Greene W. (2002). Econometric analysis. New Jersey: Prentice Hall. ISBN 0-13-066189-9.

Greene W. (2017). Econometric analysis. 8th edition. Pearson India. ISBN: 9353061075

Gupta, S., Pattillo, C. A., \& Wagh, S. (2009). Effect of Remittances on Poverty and Financial Development in Sub-Saharan Africa. World Development, 37(1), 104-115. doi: 10.1016/j.worlddev.2008.05.007.

Herman, E. (2011). The Impact of Economic Growth Process on Employment in European Union Countries. The Romanian Economic Journal, 14(42), 47-67. 
Jayanthakumaran, K. (2006). An empirical assessment of the effects of trade on employment in Australia: 1989/1990-2000/2001. Economic Papers, 25, 68-82.

Jenkins, R. (2006). Globalization, FDI and employment in Vietnam. Transnational corporations, 15, 115-142.

Jenkins, R. O., \& Sen K. (2006). International Trade and Manufacturing Employment in the South: Four Country Case-studies. Oxford Development Studies, 34(3), 299-322. doi: 10.1080/13600810600921802.

Kapsos, S. (2005).The Employment Intensity of Growth: Trends and Macroeconomic Determinants. [Employment Strategy Papers] Geneva: International Labour Office (ILO). 63 p. ILO ESP No. 2005/12.

Karlsson, S., Lundin, N., Sjöholm, F., \& Ping, H. (2007). FDI and Job Creation in China. Research Institute of Industrial Economics. Sweden, IFN Working Paper No. 723.

Lee, S.M., Olson, D.L., \& Trimi, S. (2012). Co-innovation: Convergenomics, collaboration, and co-creation for organizational values. Management Decision, 50(5), 817-831, doi: $10.1108 / 00251741211227528$

Lee, E., \& Vivarelli. M. (2006).The Social Impact of Globalization in the Developing Countries. [Discussion Papers]. Bonn: Institute for the Study of Labor (IZA). 28 p. IZA DP No. 1925.

León-Ledesma, M., \& Piracha, M. (2004). International Migration and the Role of Remittances in Eastern Europe. International Migration, 42, 65-83. doi: 10.1111/j.0020-7985.2004.00295.x.

Liu, L. (2012). FDI and Employment by Industry: A Co-Integration Study. Modern Economy, 3 (1), 16 - 22. doi: 10.4236/me.2012.31003.

Lukáčik, M., Lukáčiková, A., \& Szomolányi, K. (2011).Panel data in Gretl software. Retrieved April 25, 2018, from <http://www.fhi.sk/files/katedry/kove/vedavyskum/prace/2011/Lukacik-Lukacikova-Szomolanyi2011.pdf $>$.

Mogab, J. Kishan, R. \& Vacaflores, D. E. (2013). Labor Market Rigidity and Foreign Direct Investment: The Case of Europe. Applied Econometrics and International Development, 13(1), 35-54.

Palan, N., \& Schmiedeberg, C. (2010). Structural convergence of European countries. Structural Change and Economic Dynamics, 21(2), 85-100.

Radulescu, M., Fedajev, A., Sinisi, C. I., Popescu, C., \& Iacob, S.E. (2018). Europe 2020 Implementation as Driver of Economic Performance and Competitiveness. Panel Analysis of CEE Countries. Sustainability, 10, 566. doi:10.3390/su10020566

Sen, K. (2008). International Trade and Manufacturing Employment Outcomes in India: A Comparative Study. [Working Papers] Manchester: World Institute for Development Economics Research (UNU-WIDER). 26 p. WP No. RP2008/87.

Şerb, D., Cicioc, N., Păun, M., \& Funieru, C. (2016). Employment Level Analysis from the Determinant Factors Perspective. EcoForum Journal, 5(1), 266-273.

Simionescu, M., Dobeš, K., Brezina, I., \& Gaal, A. (2016). GDP rate in the European Union: simulations based on panel data models. Journal of International Studies, 9(3), 191-202. doi: $10.14254 / 2071-8330.2016 / 9-3 / 15$

Spiezia, V. (2004). Trade, FDI and Employment: Some Empirical Evidence. In E. Lee and M. Vivarelly eds. Understanding Globalization, Employment and Poverty Reduction, Palgrave Macmillan, New York, Palgrave Macmillan, 143-163.

Stanila, L., Andreica, M. E., \& Cristescu, A. (2014). Econometric Analysis of the Employment Rate for the E.U. Countries. Procedia - Social and Behavioral Sciences, 109, 178-182. doi: 10.1016/j.sbspro.2013.12.440. 
Suedekum, J., \& Blien, U. (2004). Wages and Employment Growth: Disaggregated Evidence for West Germany [Discussion Paper]. Bonn: Institute for the Study of Labour, (IZA). IZA DP No. 1128.

Vacaflores, D. E. (2011). Was Latin America Correct in Relying in Foreign Direct Investment to Improve Employment Rates? Applied Econometrics and International Development, 11(2), 101-122.

World Bank (2017). GDP growth (annual \%). Retrieved May 4, 2018, from $<$ https://data.worldbank.org/indicator/NY.GDP.MKTP.KD.ZG〉.

World Economic Forum (2014). The Europe 2020 Competitiveness Report. Retrieved May 6, 2018, from <http://www3.weforum.org/docs/WEF_Europe2020_Competitiveness Report_2014.pdf>.

Zaharia, M., \& Bălăcescu, A. (2013). Convergences And Divergences Of Employment Rate In UE28 A Statistical Analysis Of 2000-2012 Period. Annals of the „Constantin Brâncuşi” University of Târgu Jiu, Economy Series, 6, 2013.

Želinský T. (2013). Environmental Kuznets Curve and the Position of Slovakia and the Czech Republic in the European Union. Economics and Management, 16(3), 4-19. 